\title{
瞬きにより明らかになったデフォルト・モード・ ネットワークの新なな役割
}

大阪大学大学院生命機能研究科

中野 珠実

\section{A New Role of Default Mode Network Revealed by Eyeblink}

\author{
Tamami NAKANO \\ Graduate School of Frontiers Biosciences, Osaka University
}

\begin{abstract}
Default mode network is a network of brain regions that are active during internal processing but deactive during goal-oriented task. We previously found that while viewing videos, cortical activity momentarily decreases in the dorsal attention network after blink onset but increases in the default-mode network. Because eyeblinks tend to occur at implicit breakpoints while viewing videos, eyeblinks are involved in the release of attention by momentarily activating the default-mode network while deactivating the dorsal attention network. These results suggest that the default mode network plays an important role for neural information processing through dynamical interaction with other brain networks even during the goal-oriented task.
\end{abstract}

Key words : default mode network, eyeblink, synchronization, chunking, attentional disengagement

【要 約】デフォルト・モード・ネットワークは, 外的な処理を行っているときは活動が低下し, 内的な処理を行 っているときに活動増加を示す神経ネットワークである。筆者らは，映像観察時の瞬きに関連して，脳の中で は，デフォルト・モード・ネットワークが一過性に賦活する一方，注意の神経ネットワークの活動が一過性に抑制 されることを発見した。行動研究により，映像情報の暗黙の切れ目で，人々が一斉に瞬きをしていたことから， 瞬きは連続した視覚情報の分節化と関係していることが推測される。このことから, 外的に注意を向けている状 態でも, 瞬目に伴い, 拮抗する神経ネットワークの状態を一過性に変動させることで, 注意を内的に解除し, 情報 の分節化が行われていることが示唆される。この発見により，デフォルト・モード・ネットワークは，内的処理 を担っているだけでなく, 他の神経ネットワークと相互作用することで, 積極的な認知処理機能を担っている可 能性が考えられる。

2013.8.26受稿，2013.8.26受理，2013.11.25 J-STAGE早期公開，doi: 10.5674/jjppp.1303si, JOI: JST.JSTAGE/jjppp/1303si 連絡者及び連絡先：テ565-0871 大阪府吹田市山田丘1-3 大阪大学大学院生命機能研究科 中野珠実

E-mail: tamami_nakano@fbs.osaka-u.ac.jp 


\section{デフォルト・モード・ネットワークとは}

1970年代にポジトロン断層法 (PET), さらに 1990 年代に機能的磁気共鳴画像法 (fMRI法) が開発され てから，どのような課題を遂行しているときに脳のど こが賦活しているか, という脳機能マッピングの研究 が急速に進展してきた。それと同時に, 課題中は活動 が低下しているのに，休唕中に活動が増加するという 逆の賦活パターンを示す脳領域の存在が様々な研究で 報告されたが, それが何を意味するのか誰もわからず, 放置されていた。そんな中, 1997年にShulmanらは, PET研究のメ夕解析を行い, 課題の内容に関わらず, い つも共通の脳領域が活動低下を示すこと, それらの領 域は安静時や課題をパッシブに遂行している時には活 動が増加することを報告した（Shulman et al., 1997）。 しかし, 脳血流の増減というのは, ベースラインとの 比較になるため, この現象をべースラインの設定によ る問題と切り離せずにいた。そこで, Raichleらは, 酸 素摂取率などの指標を使うことで，ある特定の脳領域 では, 課題によって活動低下が生じていること, 逆に 安静時には活動増加が生じていることを実証し，これ らの脳領域を “default mode of the brain” と名付けた (Raichle et al., 2001)。この "default mode of the brain" には, 前頭葉内側部, 前帯状回, 後帯状回, 下頭頂小 葉などの広範な脳領域が含まれる。その後, 血流動態 の相関を調べる方法や独立成分分析法 (ICA) を適用 することで，これらの広範に広がった脳領域は， $0.1 \mathrm{~Hz}$ 以下のゆっくりした時間スケールで自発的に 相関した神経活動をしていることが明らかになってき た。このため, 現在では, これらの脳領域をデフォルト・ モード・ネットワーク (default mode network, DMN) と称すことが多い。Raichleらの一連の研究により, デフォルト・モード・ネットワークの研究は一気に開 花し，その機能に始まり，疾患との関連性まで，この 10 年で膨大な数の研究が行われており, 脳機能イメー ジング分野の中では最もホットな研究テーマのひとつ となっている。

では，このデフォルト・モード・ネットワークはど のような機能をしているのだろうか。実は, 課題の種 類によっては，デフォルト・モード・ネットワークの 活動が増加を示すことがある。例えば，デフォルト・ モード・ネットワークの主要な領域のひとつである内
側前頭葉は, 自己言及課題で特に活動が増加すること が報告されている (Gusnard, Akbudak, Shulman, \& Raichle, 2001)。さらに，思考があれこれとめぐって いる状態に関連して, デフォルト・モード・ネット ワークの中でも, 後部帯状回の活動が特に増加する (Mason et al., 2007)。さらに, 他者の心的状態を推 測するような心の理論課題を遂行しているときに賦活 する脳領域は，デフォルト・モード・ネットワークと オーバーラップしている (Amodio \& Frith, 2006)。 また, 自伝的記憶を思い起こす課題でも, デフォルト. モード・ネットワークとオーバーラップする領域が賦 活する。これらの様々な研究から推測すると, デフォ ルト・モード・ネットワークは，過去を振り返ったり， 将来のことをあれこれおもったり，自分自身や他者の 心理的状態を推察したりなど，内的な思考に関連した 処理に関与している可能性が高い。一方, 外的な刺激に 注意を向けている状態では活動が抑制されることから, デフォルト・モード・ネットワークは, 我々の頭の中 をよぎる様々な心象や思考を連綿と紡ぎだしているの かもしれない。

デフォルト・モード・ネットワークは, 外的処理の 間は活動が低下し, 内的処理の間に活動が増加するが, それとは逆の活動を示す脳領域はあるのであろうか。 Fox らは, 安静時の脳血流の自発的な変動を計測し, デフォルト・モード・ネットワークと逆相関を示す神 経ネットワークが存在することを突き止めた (Fox et al., 2005)。この神経ネットワークには, 前頭眼野 $(\mathrm{FEF})$, 上頭頂小葉 $(\mathrm{SPL})$, 第五視覚野 (MT野) な ど，注意をどの対象に向けるか制御することに関与し た脳領域から構成されていた。この二つの神経ネット ワークが自発的に逆相関した脳活動を示すという結果 は，ネットワーク間の拮抗した相互作用により，外的 処理モードと内的処理モードの状態間を遷移すること が考えられる。すると, この神経ネットワーク間の相 互作用が上手く働かない場合は, 適切な処理が行えな いのであろうか。実際, 高度な注意を要する視覚課題 を遂行させているときに, エラーや反応遅延などパ フォーマンスが低下した試行中の脳活動を調べると, デフォルト・モード・ネットワークの活動抑制レベル が低下していることが報告されている（Weissman, Roberts, Visscher, \& Woldorff, 2006)。また, 難易度 の高い運動課題などを遂行させているとき，まだ課題 
に慣れないうちは, デフォルト・モード・ネットワーク の活動が抑制されているが, 課題に慣れるとともに, デフォルト・モード・ネットワークの活動は上昇して くる (Mason et al., 2007)。これらの研究は, 外的処理 の課題中にデフォルト・モード・ネットワークが活動 すると, 課題へのエフォートやパフォーマンスが下が るということを示している。つまりは, 外的注意を要 する課題では，デフォルト・モード・ネットワークは ずっと抑制されているのが望ましいことになる。しか し, 筆者らは, 近年, この予想を覆す興味深い現象を 発見した。映像を集中して観察しているときの脳活動 を調べたところ，自発的に生じた瞬きのたびに，デ フォルト・モード・ネットワークの活動が一過性に上 昇することを発見した (Nakano, Kato, Morito, Itoi, \& Kitazawa, 2013)。なぜこのような現象が生じるので あろうか。それを検討するために，まずは，「瞬き」 の機能的役割について紹介する。

\section{自発性瞬目の機能とは何か}

瞬きには，大きく三つの種類がある。突然の音や 光, 風などに誘発されて生じる反射性瞬目, 意図的に 瞼を閉じる随意性瞬目, そして, それ以外の, 特に要 因なく生じるものが自発性瞬目である。我々は，およ そ3秒に 1 回の割合で瞬きを行っているが，その大半 は自発性瞬目にあたる。この自発性瞬目は, 眼球湿潤 という生理的機能のために生じていると一般的に認識 されている。そこで, いまから 80年以上前の1927年, イギリスの生理学者らは, 眼球表面の乾燥により瞬目 率が増加するかを調べた。実験の目的がわからないよ うにするため, 様々な理由をつけて被験者を大学の植 物用温室や, 湿度の高いトルコ風呂に連れて行き, 湿 度の異なる場所での瞬目頻度を比較した (Ponder \& Kennedy, 1927)。その結果, 驚くべきことに, 瞬目の 頻度は空気中の湿度の影響を全く受けていなかったの である。その後, 眼球表面の湿潤度をカメラで計測し た研究により, 眼球湿潤のためには, 1 分間に 3 回ほ どの瞬きで十分であることが明らかになった（Doane, 1980)。つまり, 我々は, 眼球湿潤に必要とされる回 数の 5 倍も瞬きをしているのである。1回の瞬目によ り, 眼瞼はおよそ300ミリ秒間閉じられている。1分 間に20回瞬目する場合, 覚醒時の約 1 割の時間は,
瞬目によって視覚情報の入力が遮断されていることに なる。このような多大な犠牲を払ってまで, 頻回にす る瞬目には, 眼球湿潤以外にも何らかの機能的役割が あるのではないだろうか。

眼球表面の乾燥度は瞬目率に全く影響を及ほささな かったが, 一方で, 精神状態によって瞬目率は大きく変 動する (Karson, 1983; Ponder \& Kennedy, 1927; Stern, Walrath, \& Goldstein, 1984)。怒っているときや緊張 しているときなどは瞬目率が非常に高くなる。また, 瞬目率は, 課題によっても大きく変わる。視覚課題で は瞬目が抑制される一方, 聴覚課題では瞬目が増加す る。さらに, 二重課題のように, 難易度が上がると, 視覚課題でも急激に瞬目が増加する。このように, 瞬 目率と精神状態の関係は複雑ではあるが, 自発性瞬目 が中枢性の要因によって発生しているのは間違いない ようだ。

\section{瞬きと分節化一映像観察時の瞬きの研究}

それでは, 一体, 中枢性のどのような機能に関連して, 瞬きをしているのだろうか。そこで, 筆者は, 瞬目率 ではなく, 瞬目のタイミングに着目した。もし瞬目が, 何らかの機能的な役割をはたしているのであれば，同 じ映像をみているときは, 皆同じ夕イミングで瞬目を するのではないだろうか。その仮説を検証するため に，ストーリーのある3分半のビデオを 3 回繰り返し 提示し，それを観察している人の瞬目のタイミングが 個人内・個人間で同期するかを調べてみた (Nakano, Yamamoto, Kitajo, Takahashi, \& Kitazawa, 2009)。 使用した映像刺激は, イギリスの人気コメディ番組 “ミスター・ビーン”を編集したもので, 音声なしで も話の内容が理解でき, かつストーリーが次々に展開 されるので, 見逃せないシーンが豊富という理由で選 んだ。また，コントロール条件として，どこで瞬目を しても映像の認知に影響しないような映像刺激（熱带 魚が泳いでいる映像やエーゲ海の風景映像）を提示し ている時と, 人気小説 “ハリーポッター”の朗読音声 を聞いている時の瞬目のタイミングも計測し, 同様に 同期が生じるかを調べた。瞬目は垂直眼電図 (EOG) を用いて計測し, 瞬目開始時刻を検出したあと, 個人 内・個人間で瞬目時間のずれの分布を算出した。さら に, この分布がランダムに同期する確率と比較して有 
意に偏っているかを調べるために, 瞬目の生起間隔を ランダムにシャッフルして作り上げた疑似データ（サ ロゲートデータ）を1000個生成して統計解析を行った。 その結果, ミスター・ビーンの映像を見ている条件の ときだけ，個人内・個人間とも瞬目の夕イミングが 0 ミリ秒近辺で有意に同期していたのである（図1）。

それでは, どんな場面で瞬目が同期していたのであ ろうか。読書をしているときの瞬目を調べた研究で は, 句読点や改行などの明示的な切れ目で瞬目が発生 していることが報告されているが，映像をみていると きの瞬目の同期も, 場面の切り替えなどの明示的な切 れ目で生じていたのであろうか。そこで, 場面の切り 替えに伴う瞬目発生頻度を解析したところ, 確かに場 面の切り替わり後, 400-600ミリ秒のあたりで, 瞬目 発生頻度が有意に増加していた。しかし，この時間带 に発生した瞬目を取り除いても, 瞬目の同期度はほと んど変化せず，相変わらず 0 ミリ秒近辺で有意に高い 值を示していたのである。つまり，場面の切り替わり は自発性瞬目を誘発する傾向があるものの，必ずしも 同じ場面の切り替わりのところで皆が一斉に瞬目をし ているわけではないようである。そこで, 参加者全員 の瞬目頻度の時系列デー夕を調べると, 3 分半の映像 の中で際立ったピークが何か所も見受けられた。この ピークの高い順に瞬目を取り除いて瞬目同期度の変化 を調べると, 約 3 割の瞬目を取り除いた時に瞬目の有 意な同期が消失した。つまり, 自発性瞬目のうち，3割 程度はこの同期現象に関与しているのである。さらに, このピークが生じていた具体的な場面を調べたところ，
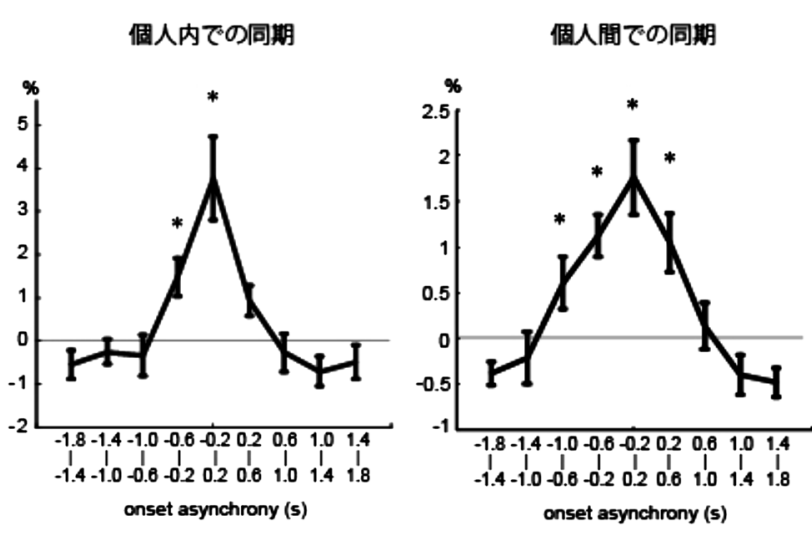

図1。ミスター・ビーンの映像を観察しているとき の, 個人内, 個人間の瞬目発生タイミングのずれの分布

$0 \mathrm{~ms}$ 近辺で有意に瞬目の割合が増加していることから, 瞬きのタイミングが同期していることがわかる。
ミスター・ビーンが車から乗り降りをした瞬間や車が 駐車した瞬間など, 映像内容の非明示的な切れ目で選 択的に瞬目同期が生じていることが明らかになった。 つまり, 我々は無意識に環境の中から出来事のまとまり をみつけ, その切れ目で瞬目を行っており, またその 瞬目の夕イミングが人々の間で共通しているのである。

\section{瞬きの社会的機能}

\section{一二者間の瞬きの引き込みに関する研究}

同じ映像を見ているときは，皆同じタイミングで瞬 きをしていることがわかったが, さらに, 社会的な相 互作用に瞬きは何か影響をおよぼしているであろうか。 例えば, 視線の場合, 我々は他者の目の向けた方向に 追従して同じ対象を注視する行動（共同注視）を無意 識に行っており, この行動は他者との円滑なコミュニ ケーションには欠かせないものである。同様に, もし 瞬目が情報の切れ目を表出しているとすれば，その切 れ目を他者と能動的に共有するようなことはおきてい ないだろうか。そこで, 筆者らは, 対面会話時に, 話 し手の瞬目と聞き手の瞬目が同期しているかを調べて みた (Nakano \& Kitazawa, 2010)。本来は, 実際に2人 の人間が向かい合って会話している状況下で調べるの が理想であるが, 瞬目率は個人差が非常に大きく, また 会話の質の統制も難しい。そこで, 参加者の間で実験 の条件を統一するために，正面を向いて演説をしてい る人物の顔の映像を提示し, それを視聴している14名 の参加者の瞬目を垂直EOG法により計測した。参加 者には, スピーチの内容に関して後で質問に回答して もらうことと，目の動きを計測することを伝えており， 瞬目を計測するという研究の本当の目的は教えていな い。映像刺激は, 俳優の木村拓哉が日本の総理大臣と して国民に向かってテレビ演説をしているというドラ マのワンシーンを編集して提示した (CHANGE，フ ジテレビ)。このドラマは, 10 分以上にわたる主人公 の熱い演説をワンカットで撮影したことで話題になっ たものである。まず話し手 (木村拓哉) の瞬目の開始 時刻をビデオ解析により抽出し, 聞き手 (参加者)の 瞬目の開始時刻とのずれを解析した。さらに, 聞き手 の瞬目間隔を取り出してランダムシャッフルして生成 した 1000 個のサロゲートデータの平均と標準偏差を 計算し, 実データの分布の統計解析を行った。すると, 
音声と映像の両方を提示した条件では, 話し手の瞬目 開始時刻から 250〜 500ミリ秒遅れたところで, 聞き 手の瞬目生起確率が有意に増加していたのである（図 2 上)。このような話し手の瞬目への聞き手の瞬目の 引き込みは，映像の久提示した条件では生じなかった ことから，単に相手の瞬目を見ることで自動的にそれ を模倣したことにより起きた現象ではない。また，音 声のみ提示した条件でも同様に瞬目の引き込みは生じ ていなかったことから, 音声情報の途切れが聞き手の 瞬目を誘発したわけでもなく, “対面して話を聞く” という状況に対して特異的に生じた現象だといえる。 そこで，この瞬目の引き込みがスピーチのどこで生じ ていたのかを明らかにするために，まず話し手の瞬目 開始時刻の前後1秒間の音声波形を取り出し, 整流後 に平滑化したデータをクラスター解析したところ,
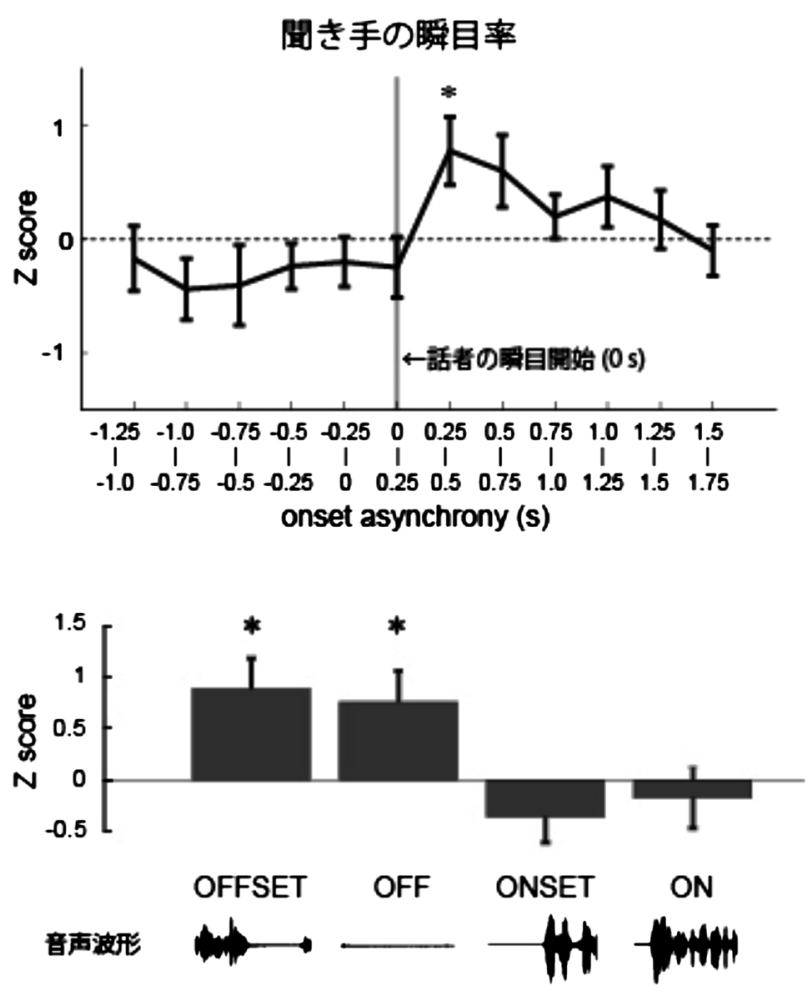

図2. 対面時における話者と聞き手の二者間での瞬目 同期

（上）話者の瞬目開始を 0 秒で揃えたときの, 聞き手の瞬 目発生率の時間変化 話者の瞬目から $0.25-0.5$ 秒遅れて有 意に聞き手の瞬目が増加している。（下）話者の瞬目の発 生タイミング別の瞬目引き込み 話者の瞬目発生時の前後 1 秒の音声波形のクラスター別に, $0.25-0.5$ 秒の時間にお ける聞き手の瞬目の増加率を比較したものである。発話の 終了あるいは合間で生じた話者の瞬きに対して特異的に聞 き手の瞬きの有意な増加がみられる。
4 グループに最適に分割された（図 2 下）。その結果, 今回提示した映像では, 約7割の瞬目は発話の合間 (OFFタイプ), あるいは発話の終わり（OFFSETタイ プ）で生じており，約2割の瞬目が発話開始時 $(\mathrm{ONSET}$ タイプ), 残り1割が発話中 (ONタイプ) に 生じていた。次に, この話し手の瞬目タイプ別に聞き 手の瞬目の引き込み度合いを調べたところ，なんと OFFSETかOFFタイプの話し手の瞬目に対してのみ, 聞き手の瞬目の増加が起きており, ONSETやON夕 イプでは, むしろ聞き手の瞬目は抑制されていた（図 2 \#)。つまり, 話の句切れ目で生じた話し手の瞬目 に対してのみ，聞き手の瞬目が引き込まれていたので ある。この瞬目の引き込みは, 対面して話を聞いてい る時にのみ生じる現象であることからも, 瞬目を介し て情報のまとまりを無意識に共有するという過程を反 映していると考えられる。一連の研究から, 瞬目が個 人内の情報処理だけでなく, 個人間の相互作用という 社会性認知においても重要な役割を果たしていること が初めて明らかになった。

この対面会話時における話者と聴者の瞬目同期現象 は，両者のコミュニケーションの質に対してどのよう な効果を及ぼしているのであろうか。瞬目を介して話 の切れ目を無意識に共有することが相互理解や共感性 を高め, その結果コミュニケーションの促進につな がっている可能性が考えられる。もしそうであれば, コミュニケーションの障害が主症状である自閉症にお いては, 対面会話時に他者との間に瞬目の同期が成立 していない可能性がある。そこで, 健常な成人に見せ たのと同じビデオ映像を提示し，それを視聴している 成人の自閉症スペクトラム症候群 18 名の瞬目と注視 点を計測した (Nakano, Kato, \& Kitazawa, 2011)。参 加者はアスペルガー症候群 (10名) か, 高機能自閉症 (8名) と診断されており, IQスコアも健常群と同程 度であり, 実験終了後に行ったスピーチの理解度テス トでも，健常者と同様に正しく話を理解できていた。 それにもかかわらず，健常者でみられる話者の瞬目へ の引き込みが生じていなかった。しかし，そもそも自 閉症群は話者の顔をあまり見ていなかったから, 瞬目 の引き込みが扔きなかった可能性も十分考えられる。 その可能性を検討するため, 映像視聴時の彼らの注視 点を解析した。その結果, 話者の目と口への注視割合 は, 目は $56 \%$, 口は $24 \%$ となっており, 健常群の目 
は $56 \%$ ， 口は $33 \%$ と有意な違いがなかった。さらに， 話者の瞬目タイプ別に瞬目率の増加率を調べたとこ ろ，健常群でみられたような発話の終了(OFFSET), 合間 (OFF) で生じた話者の瞬目への引き込みが自閉 症群では生じていないことがわかった。つまり, 話の 切れ目で話者が瞬目をしても, 自閉症群の瞬目発生パ ターンにはほとんど影響を及ぼさないのである。これ らの結果から, 自閉症群においては, 瞬目を介して対 面している相手の話のまとまりを共有しょうとする行 為が欠如していることが明らかになった。このような 他者に同調した行為が欠落していることが, 彼らのコ ミュニケーションの障害につながっている可能性が示 唆される。

瞬きとデフォルト・モード・ネットワーク

映像観察時の自発性瞬目の同期現象から, 我々は無 意識に環境の中から最適な情報のまとまりを見つけ, その切れ目で瞬目を行っていることが明らかになっ た。もしかしたら，瞬きは，現在処理している対象か ら, 内因的に注意を解除することで, 情報の分節化を するという役割をしているのではないだろうか。この 筆者の仮説を支持する臨床的エビデンスがある。小脳 変性症により目を動かせなくなり強制注視状態にある 患者は, 瞬目をすることにより対象への注意が解除さ れ，顔を動かすことが可能になり，別の対象を見るこ とができるという症例報告がある（Wadia \& Swami， 1971)。また, 生後数か月までの乳児は, 顕著な刺激 に定位することはできるが，一度注視するとそこから 目を離すことができない状態に陷る。乳児の瞬目率は 1分間に2-3回と極めて少なく, 年齢とともに瞬目率 は増加することを考えると, 内発的に注意を解除する 能力と自発性瞬目の間には深い関係があることが推測 される。

注意の制御には, 現在の対象への注意の解除と, 次 の対象への定位が必要であるが，これらのプロセスは 互いに独立した神経メカニズムが関与していると提唱 されている (Posner, Walker, Friedrich, \& Rafal, 1984)。 次の対象への定位には, FEF と SPLを中心とした神経 ネットワークが中心となって機能していることがよく 知られている (Corbetta \& Shulman, 2002)。一方, 注 意解除の神経メカニズムはほとんど明らかになってい
ない。そこで, 瞬目による情報分節化の神経機構を明 らかにするため, 筆者らは, 3 章で紹介した行動害験と 同様に, ストーリーのある映像 (“ミスター・ビーン”) を見ている時の瞬目に関連して, 脳内にどのような変 化が生じているかを磁気共鳴機能画像法 (fMRI法) に より調べた (Nakano et al., 2013)。すると, 瞬目に応 じて, 注意ネットワークの主要な領域であるFEFと SPLの脳活動が一過性に減少していた（図3)。一方, 課題時よりも安静時で活動が上昇し，内的な情報の処 理に関連しているとされ，近年多大な関心を集めてい
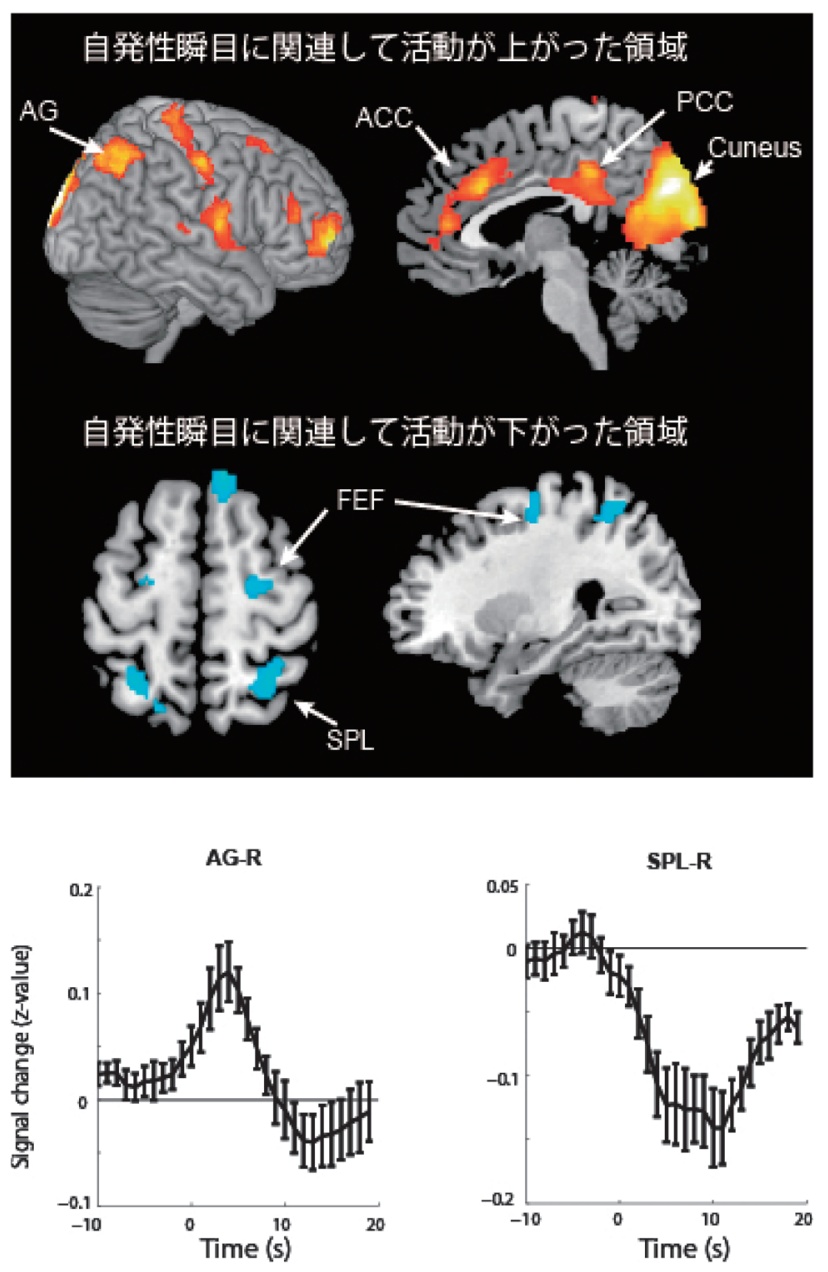

図3. 自発性瞬目に伴う脳活動変化

（上）映像を観察時の自発性瞬目に関連して, 内側視覚 野 (Cuneus) だけでなく, DMN関連領域である前帯状回 (Anterior Cingulate Cortex, ACC), 後帯状回 (Posterior Cingulate Cortex, PCC), 縁状回 (Angular Gyrus, AG) の 活動が一過性に上昇する。(中)一方, 注意ネットワーク に属する前頭眼前野 (Frontal Eye Field, FEF), 上頭頂葉 (Superior Parietal Sulcus, SPL) の活動が一過性に低下し た。（下）DMNに属する AGと, 注意ネットワークに属す るSPLの, 瞬きに関連した血流変化の加算平均波形。瞬き が生じた瞬間を0秒としている。 
るデフォルト・モード・ネットワークの脳領域の活動 が，瞬目に関連して一過性に上昇していたのである。 このデフォルト・モード・ネットワークと注意の神経 ネットワークは, 安静状態では数十秒の時間オーダー で自発的に逆相関した活動を示すことは知られていた が (Fox et al., 2005), 驚くべきことに, 課題中でも, 数秒に 1 回生じている瞬目の度に, 両者のネットワー クの活動の交替が生じているのである。一方, 瞬きと 同じ時間幅で映像をブラックアウトさせた場合, デ フォルト・モード・ネットワークの一過性の上昇と注 意のネットワークの活動減少は生じていなかったこと から, 映像の物理的な遮断がこのような脳活動変化を 引き起こしているのではなく, 瞬きに特異的に伴う現 象である。これらの研究結果を踏まえると, 自発性瞬 目は，拮抗する神経ネットワークの状態を一過性に変 動させることで, 注意を内的に解除し, 情報の分節化 を行う機能的役割を担っている可能性が考えらえる。 さらに, 外的に注意を向けている状態でも, 数秒に 1 回 という高頻度で, デフォルト・モード・ネットワークと 注意のネットワークの活動交替が生じていることから， 脳の情報処理にとって，このように頻回に情報を分節 化する何らかの必要性があるのであろう。筆者は, 大 脳皮質における短期記憶のバッファ容量と関係がある のではないかと推測しているが, 今後の研究の進展に より,この問題が解明されることを期待している。

\section{まとめ}

\section{一デフォルト・モード・ネットワークの新たな機能}

デフォルト・モード・ネットワークは, 外的に注意 を向ける課題では活動が低下するのに対し, 内的な処 理を行っているときに活動増加を示す神経ネットワー クである。デフォルト・モード・ネットワークは, 注 意の神経ネットワークと自発的に逆相関の活動パター ンを示すことから, 両者の神経ネットワークの拮抗的 相互作用が, 脳の情報処理あるいは意識状態を内的・ 外的モードの間で遷移させていると考えられる。筆者 らは, 映像観察時に情報の暗黙の切れ目で, 人々が一 斎に瞬目をすることを発見した。この映像観察時の瞬 きに関連して, 脳の中では, デフォルト・モード・ ネットワークが一過性に賦活する一方, 注意の神経 ネットワークの活動が一過性に抑制されていた。この
ことから, 外的に注意を向けている状態でも, 瞬目に 伴い，拮抗する神経ネットワークの状態を一過性に変 動させることで, 注意を内的に解除し, 情報の分節化 が行われていることが示唆される。つまり，デフォル ト・モード・ネットワークは, 内的処理を担っている だけでなく，常に他の神経ネットワークと相互作用す ることで, 積極的な認知処理機能を担っている可能性 が考えられる。

\section{引用文献}

Amodio, D. M., \& Frith, C. D. (2006). Meeting of minds: the medial frontal cortex and social cognition. Nature Reviews Neuroscience, 7, 268277.

Corbetta, M., \& Shulman, G. L. (2002). Control of goal-directed and stimulus-driven attention in the brain. Nature Reviews Neuroscience, 3, 201-215.

Doane, M. G. (1980). Interaction of eyelids and tears in corneal wetting and the dynamics of the normal human eye blink. American Journal of Ophthalmology, 89, 507-516.

Fox, M. D., Snyder, A. Z., Vincent, J. L., Corbetta, M., Van Essen, D. C., \& Raichle, M. E. (2005). The human brain is intrinsically organized into dynamic, anticorrelated functional networks. Proceedings of the National Academy of Sciences of the United States of America, 102, 9673-9678.

Gusnard, D. A., Akbudak, E., Shulman, G. L., \& Raichle, M. E. (2001). Medial prefrontal cortex and self-referential mental activity: relation to a default mode of brain function. Proceedings of the National Academy of Sciences of the United States of America, 98, 4259-4264.

Karson, C. N. (1983). Spontaneous eye-blink rates and dopaminergic systems. Brain; a journal of neurology, 106 (Pt 3), 643-653.

Mason, M. F., Norton, M. I., Van Horn, J. D., Wegner, D. M., Grafton, S. T., \& Macrae, C. N. (2007). Wandering minds: the default network and stimulus-independent thought. Science, 315, 393395.

Nakano, T., Kato, M., Morito, Y., Itoi, S., \& Kitazawa, 
S. (2013). Blink-related momentary activation of the default mode network while viewing videos. Proceedings of the National Academy of Sciences of the United States of America, 110, 702-706.

Nakano, T., Kato, N., \& Kitazawa, S. (2011). Lack of eyeblink entrainments in autism spectrum disorders. Neuropsychologia, 49, 2784-2790.

Nakano, T., \& Kitazawa, S. (2010). Eyeblink entrainment at breakpoints of speech. Experimental Brain Research, 205, 577-581.

Nakano, T., Yamamoto, Y., Kitajo, K., Takahashi, T., \& Kitazawa, S. (2009). Synchronization of spontaneous eyeblinks while viewing video stories. Proceedings of the Royal Society B: Biological Sciences, 276, 3635-3644.

Ponder, E., \& Kennedy, W. P. (1927). On the act of blinking. Quarterly Journal of Experimental Physiology, 18, 89-110.

Posner, M. I., Walker, J. A., Friedrich, F. J., \& Rafal, R. D. (1984). Effects of parietal injury on covert orienting of attention. Journal of Neuroscience, 4 , 1863-1874.
Raichle, M. E., MacLeod, A. M., Snyder, A. Z., Powers, W. J., Gusnard, D. A., \& Shulman, G. L. (2001). A default mode of brain function. Proceedings of the National Academy of Sciences of the United States of America, 98, 676-682.

Shulman, G. L., Corbetta, M., Fiez, J. A., Buckner, R. L., Miezin, F. M., Raichle, M. E., \& Petersen, S. E. (1997). Searching for activations that generalize over tasks. Human Brain Mapping, 5, 317-322.

Stern, J. A., Walrath, L. C., \& Goldstein, R. (1984). The endogenous eyeblink. Psychophysiology, 21, 22-33.

Wadia, N. H., \& Swami, R. K. (1971). A new form of heredo-familial spinocerebellar degeneration with slow eye movements (nine families). Brain: $a$ journal of neurology, 94, 359-374.

Weissman, D. H., Roberts, K. C., Visscher, K. M., \& Woldorff, M. G. (2006). The neural bases of momentary lapses in attention. Nature Neuroscience, 9, 971-978. 